\title{
Adopting a human rights based approach to international Christian development
}

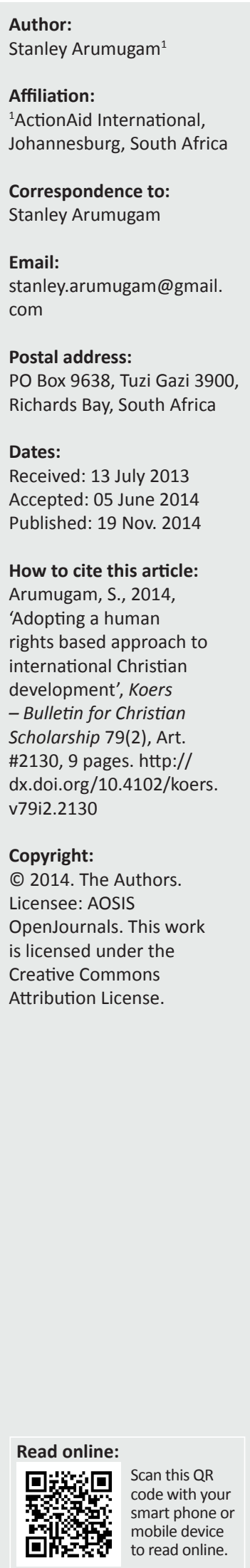

It is only in the past decade that religion has been recognised as critical to ensuring sustainable international development efforts. This is due in large part to the failure of the dominant development paradigm of Western secularism in the global South. This article focuses on the significant historical contribution of evangelical Christianity in international development and explores some of the ideological tensions that challenge partnership with secular organisations. The resulting separate and parallel efforts of evangelical Christianity and the international non-governmental organisations (INGO) sector are costly and counter-productive in serving the poor. Recently, many INGOs have adopted the human rights-based approach underpinned by its commitment to social justice and solidarity with the poor - values also central to the Bible. It will be argued that this shared approach could provide the necessary bridge to facilitate deeper engagement in the form of social action between secular development actors and evangelicals. The critical role of evangelical Christianity in addressing poverty as a human rights issue in South Africa is also dealt with briefly.

Integrasie van 'n menseregte-gebaseerde benadering tot Christelike ontwikkeling. In die afgelope dekade is godsdiens erken as van kritieke belang om die volhoubare internasionale inisiatiewe vir ontwikkeling te verseker, terwyl die dominante paradigma van die Westerse sekularisme skyn te misluk in die globale Suide. Hierdie artikel fokus op die evangeliese Christendom se belangrike historiese bydrae tot internasionale ontwikkeling en ondersoek sommige van die ideologiese spanninge wat 'n vennootskap met sekulêre organisasies bemoeilik. Die gevolglike afsonderlike en parallelle pogings van die evangeliese Christendom en die internasionale nie-regeringsorganisasie sektor (INGO) is duur en teenproduktief in die versorging van die armes. Vele INGO's het onlangs die menseregte-gebaseerde benadering, wat ' $n$ sterk verbintenis tot sosiale geregtigheid en solidariteit met die armes het, aangeneem - waardes wat sentraal is tot die Bybel. Daar sal aangevoer word dat hierdie gedeelde benadering die nodige brug kan voorsien om ' $n$ dieper betrokkenheid in die vorm van sosiale aksie tussen sekulêre ontwikkelingsagente en evangeliste te fasiliteer. Die kritieke rol van die evangeliese Christendom in die aanspreek van armoede as 'n menseregte-kwessie in Suid-Afrika word ook kortliks behandel.

\section{Introduction}

Despite the best efforts of international development agencies, the scale of global poverty still remains at a dehumaning level. Religion as a key factor in understanding and alleviating poverty has until recently been ignored by international non-governmental organisations (INGOs). This article attempts systematically to explore the humanitarian efforts of Western evangelicals in the global South; their engagement with the predominantly secular INGO sector, and their response to addressing poverty as a human rights issue. Lessons for evangelical engagement in the South African context will also be explored briefly.

This article is based on a presentation at a University of South Africa conference on 'Christian leadership in the national and global workplace'. The author reflects on his personal experience as an evangelical Christian working in a 'secular' INGO, ActionAid International. The author argues that the 'sacred-secular' ideological divide is less important when the poor are always central to the focus of work either by evangelicals or by secular agencies. It has been the author's experience that ActionAid is deeply committed to biblical values of social justice and concern for the poor, oppressed and marginalised despite its secular identity. There is a great opportunity for both the INGO sector and evangelicals to learn from and work with one another, instead of 'demonising' the other (see ActionAid 2012). 


\section{Secularism as the dominant ideology of international development}

The predominant change paradigm of economic development heralding the United Nation's (UN) ambitious development plan in the 1970s and 1980s failed in large part because it did not deal with the root causes of poverty, including the centrality of religion, especially in the global South. The big idea of 'development' derived from the Cold War politics of the United States of America (USA) and Europe reduced international development efforts to an economic solution: 'get countries to be economically viable and poverty will be alleviated'. Helping poor nations become more viable was also the driving hope that would make them less susceptible to the rising tide of communism, as it was theorised, since poverty creates more revolution than ideology (Bragg 1989:64).

The underlying thesis of secularism, that is, suggesting that religion is unimportant and that it will become redundant as nations develop, has been denounced as an ideological and doctrinal project requiring urgent revision as witnessed by the worldwide resurgence of religion in the late 20th century (Gelot 2012). The wholesale acceptance of secularism in Western Europe as the prevailing norm for the rest of the world has also been challenged by Shortt (2012), who argues that almost all other societies display high levels of religious belief and practice. In fact, three-quarters of humanity professes religious faith and that faith, Shortt says, is projected to reach the $80 \%$ mark by 2050 .

Secularism as the dominant Western development paradigm remained unchallenged until the last decade. Many INGOs and institutional donors such as the World Bank and the European Union (EU) traditionally excluded religion from their development policies. In 2006, Ter Haar and Ellis called for a revision of the EU's development policies, especially those towards the global South - where religion is a defining dimension of social and political reality:

The notion and norm of secularisation has fostered a kind of religious illiteracy ... It might not have been the intention, but ignoring religion has in fact become a way of showing arrogance towards people for whom religion is important. We have to realise, again, that the normal situation for most people is to be part of a religion which influences their lives and actions. (Moksnes \& Melin 2013:3)

A significant manifestation of secularisation has been the institutional separation of religion and politics in Europe that the continent exported to other parts of the world, especially during colonialism. Ter Haar (2013) argues that this colonial approach has imposed on and clashed with the indigenous spirit-orientation common in African religious belief in sub-Saharan Africa. Western outsiders have commonly regarded people's concern with the spiritual world as an escape from 'real problems', such as corruption and human rights violations. However, Ter Haar (2013) argues that the notion of transformational social change which is much emphasised by Western development agencies, as in the rights-based approach, does in fact have a strong resonance in new as well as traditional religious thought in many regions of Africa.

The past decade has seen a flurry of activity in the international development sector in an attempt to understand the impact of religion on development efforts, largely driven by Western donor demands (Jones \& Petersen 2011). This sudden interest might be the result of several factors. Perhaps most importantly this arises from the crisis within secularism which up to now has been taken for granted as the dominant and valid paradigm of international development (Gelot 2012). The need for revision has opened up new opportunities for dialogue between development professionals and faith-based actors.

\section{Role of religion in international development}

What role do religion and faith-based organisations play in addressing global poverty? Hiebert \& Hiebert-Crape (1995) assert that religion is central to human anthropology and ignoring religion through a Western dualistic lens dismisses a key aspect of international development efforts, especially in the so-called developing countries where, unlike in Europe, faith is central to life:

Given a systems view, then, what is the role of religion in development? If religion constitutes the core of a culture and defines its ultimate realities and values, then development that does not include religious change is clearly superficial and transitory. (p. 23)

\section{Moksnes \& Melin (2013) assert that:}

\begin{abstract}
it is time to take religion seriously. Not because it is more important than anything else, but because religion is part of what influences people, their values, their worldview, and their behaviour. Across the world, religious faith motivates people to mobilise around shared spiritual as well as political objectives, forming groups that sometimes are important social actors, whether within civil society or as political parties, directly engaging with state governance. Thus, by understanding the role of religion we can better understand political processes and societal developments. (p. 3)
\end{abstract}

The recent interest in religion and international development studies is long overdue but welcome; but as Jones \& Petersen (2011) argue, the underlying drivers of this interest need to be critically scrutinised. In reviewing the recent decade of literature, they put forward three broad criticisms. Firstly, it is instrumental in its approach - it is interested in understanding how religion can be used to do development 'better' as an 'add on' to other approaches such as the role of civil society, gender, and human rights. Secondly, they see the literature as narrowly focused on faith-based organisations, which is in many ways a consequence of the need to understand religion instrumentally, driven by donor relations. Thirdly, it is based on normative assumptions about how both religion and development are conceptualised: religion is understood to be apart from 'mainstream' development, whereas development is 
defined as what development agencies do without a sense of genuine or equal partnership.

At a recent international development conference hosted by Uppsala University, Sweden, in 2013, the focus was on religious civil society actors as key agents of development change and new partnerships with development sector professionals. The new partnership has also brought to the fore differences in perspectives and values, and has raised questions on how to respect and strive to overcome these in a genuine partnership of religious actors with development sector professionals (Moksnes \& Melin 2013). With diminishing government involvement in social programmes both locally and internationally, NGOs with a religious orientation have the potential to make significant contributions to the development arena and may prove to be the most effective and lasting of the development agencies (Mayotte 1998).

\section{Historical review of evangelical engagement in development}

For centuries, major world religions have been actively involved in and committed to humanitarian care and human development and much longer than the modern international development sector. From a Christian perspective, the themes of social justice, the dignity of the human person, and concern for the poor, the oppressed and marginalised are at the heart of Christian scriptures. Over the years, the church in its various forms has been a strong advocate for the poor and marginalised. By 1953, almost $90 \%$ of post war relief was provided by religious agencies. Churches working together with non-governmental organisations (NGOs) were also instrumental in lobbying for the establishment of the United Nations and in drafting the UN Charter of Human Rights (Ferris 2005).

Within Christianity, there has been a significant historical commitment to social action by evangelicals (Pierson 1989). The transformation of society has always been an essential part of the missional task starting with the forerunners of the Protestant missionary movement: puritanism, pietism, Moravianism and the Wesleyan or evangelical revivals. Such movements attempted to transform their own societies, committed to both evangelisation and service to the poor, the marginalised and the oppressed.

Sadly, the colonial history of Christian missions shows a reductionist approach to salvation and human development and has been criticised for its other-worldly focus, its alliance with prevailing power structures and its disregard for indigenous cultures and values. Interestingly, Shik (1983:168) argues that the same critique holds true for international development which is more similar than different in the following ways: (1) association with imperial powers; (2) Western models as superior, treating indigenous cultures as heathen or under-developed according to a Western norm of development; (3) people become the objects of the missionary message or the development programme, which is imposition and not partnership; (4) both obsessed by different versions of salvation - saving souls and saving the world. Given these similarities, both paradigms of secular international development and global Christian missions are flawed in their reductionist approach to the plight of the poor.

A brief survey of American and British evangelical social engagement will be useful in facilitating an understanding of both its significant impact on social change and also on the underlying ideological tensions which makes sacredsecular development partnerships challenging. Smith (1989) surveys American evangelical engagement in missions and international development from the 1900s to the last decade. Despite the early tradition of social engagement as part of a holistic mission, the early 1900s witnessed significant ideological upheaval in fundamentalist-modernist debates, resulting in the 'Great Reversal' in 1925. Progressive social concern was nearly eliminated with an emerging polarisation of fundamentalists who believed evangelism was separate from social concern whilst those who proposed a 'Social Gospel' were labelled as theological liberalists. The 1960s brought deep social discontent in many young evangelicals disillusioned with the apathy and opposition of evangelicalism to the Civil Rights Movement. The 1970s saw a resurgence of evangelical development work concerned with social issues, international politics and Third World poverty. Since then the work of American evangelicals has grown steadily into the current decade.

Similar evangelical social action movements took place in Britain and in parts of Europe, culminating in what evangelical theologian John Stott (2006) describes as a 'turning point for the worldwide evangelical constituency'. The significant event was the Lausanne International Congress on World Evangelization held in 1974. The conference declared that 'evangelism and socio-political involvement are both part of our Christian duty'; since then, the commitment to social action has grown in the global evangelical community. One such global movement still making a significant impact is the Micah Network - convened in Oxford in 2001 with 140 Christian leaders representing those involved with the poor from 50 countries with the idea of 'Integral Mission'. According to Chester (2002):

\footnotetext{
Integral Mission or holistic transformation is the proclamation and demonstration of the gospel. It is not simply that evangelism and social involvement are to be done alongside each other. Rather, in integral mission our proclamation has social consequences as we call people to love and repentance in all areas of life. And our social involvement has evangelistic consequences as we bear witness to the transforming grace of Jesus Christ. (pp. 2-3)
}

The past decade of growth in missions and development as an outreach of American evangelical churches in the global South is a mixed blessing. Stott (2006) warns that development action is welcome but there is a danger of an uncritical engagement, especially when it may be prone to the politicization of the Christian gospel'. It is beyond the scope of this article, but still 
important to note this new trend in US-Africa development initiatives. In 'US Evangelical Mission in Kenya', Hearn (2002) argues that the beginning of the new millennium marks not the end of the missionary era but its high point. In Kenya, American evangelical missions constitute a key agent of the US 'New Policy' Agenda which is built on the two pillars of neo-liberalism and liberal democratic theory. In 'The role of evangelical NGOs in international development: A Comparative Case Study of Kenya and Uganda', Hofer (2003) observes that faith-based NGOs with private funding have a bigger influence than their secular counterparts in subSaharan Africa and serve to actively strengthen American and Southern evangelical networks, promoting conservative values, politics and a growing interest in the privatisation of education and healthcare. There is a danger in this:

After all, the contemporary evangelical movement presents itself not as a missionary enter-prise of Westerners to save souls in the developing world, but as an international business and value coalition. (p. 396)

As a final reflection on the history of evangelical commitment, the Lausanne Movement in its 'Cape Town Commitment of 2010' illustrates the dynamic nature of modern evangelical commitment to social action which seems to be characterised by ambiguity. Despite its radical founding vision in the 1970s, in 2010 it seems to make a rather weak commitment to eradicating poverty through active social action, especially in partnership with evangelicals in the global South (see Green 2011). The old tension of the 'primacy of evangelism' seems to resurface and dominate current dialogue - still largely driven by Western evangelicals with an ambiguous commitment to global human rights.

This historical survey of Christian 'development' illustrates the pioneering tradition of evangelical commitment to development which needs to be celebrated. There is also a need to revisit evangelical social action in light of the growing global challenge of poverty as a human rights issue and the need for multi-faith and secular development partnerships necessary for sustainable impact.

\section{Towards a human rights-based approach in development}

The adoption of a human rights based approach (HRBA) by international development agencies has been considered by development scholars as a paradigm shift in the sector and increasingly influences the way in which development organisations think about poverty reduction (Tomalin 2006). The difference in this approach, unlike the economichumanitarian aid approach, is that it recognises the multidimensional nature of poverty and seeks to address the root causes of poverty often located in the power base of rights holders (the poor) and duty bearers (people and institutions in elected power). Human rights-based organisations recognise the necessity of meeting the basic needs of food, water, housing, medical care and education but not as an end in itself. They recognise that unless people in power and authority (duty bearers) are accountable to serving their people (rights holders) in a fair and just manner, poverty will not be eliminated. Without achieving human rights effectively, it is hard to foresee any sustainable development (Ljungman 2004).

Unlike the traditional 'charity' model where the recipient of aid is passive, the HRB affirms the dignity of all people and their agency to change their own circumstance:

A rights based approach to development describes situations not simply in terms of human needs, or of development requirements, but in terms of society's obligations to respond to the inalienable rights of individuals, empowers people to demand justice as a right, not a charity, and gives communities a moral basis from which to claim international assistance when needed. (UN Secretary General Kofi Annan, UNHCR 2006)

Several Christian international development agencies such as Christian Aid and World Vision have adopted the HRBA without idealising its secular values. In practice, this approach promises to bring about a more sustainable change in the lives of the poor. A commitment to identifying and dealing with the root causes of poverty in solidarity with the poor shifts the agency of intervention from outside benevolent agencies (whether secular or Christian) pursuing their development agenda to an insider approach based on the lived reality of the poor. This approach of identifying with the experience of the poor is not new but has been central to Christian theology and more evidently to the development of liberation theology.

\section{Evangelicals and human rights}

This section explores the biblical imperatives for human rights engagement and then examines modern evangelical positions on human rights. Hiebert (2009) reminds us of the contextual nature of Christian engagement in society through the discipline of missiology:

The central question of missiology: how can the gospel of Jesus Christ be incarnated in human contexts so that people understand and believe, societies are transformed, and the kingdom of God is made manifest on earth as it is in heaven? (p. 33)

Taking seriously the incarnation of Christ, we recognise that God has entered our worldly reality not to provide us an escape as secularists argue but to enable us to act as his agents of change. Lorenzen (2006) identifies four imperatives that locate human rights in relation to Christianity: historical, theological, Christological and biblical.

The historical imperative: Human rights based discourse and practice is incontrovertibly Christian. Hogan (2006:71) observes that, starting in the medieval period, Christians 'moved effortlessly between the language of rights and the language of biblical texts and saw no conflict in so doing'. The modern idea of human rights started in the 16th century and 17th century, when striving for religious freedom led to a call for the separation of church and state. These freedoms were later codified in the American and French charters of freedom and later in the UN Charter of Human Rights (Ferris 2005). 
The theological imperative: In Christ, the world has been reconciled to God and the followers of Christ have been appointed as facilitators of reconciliation. The only condition was that the methods of reconciliation are consistent with the nature of the reconciler: 'we entreat you on behalf of Christ, be reconciled to God' (2 Cor 5:20). As such, a commitment to human rights is part of preparing the way of the Lord.

The Christological imperative: Christ was crucified because his passion for God included his liberating compassion to protect and heal human life, even when his divine mission clashed with the cultural and religious norms and institutions of his day. Very early, Christian theologians began to protest against the separation of faith from the poverty and particularity of Jesus' life and its consequences.

The biblical imperative: In the Bible - the source for Christian theology and praxis - we find that God has no other passion than to make human life fully human. This is evident in God's hearing and responding to the plight of the oppressed Israelites and in the special care of the codes of law providing for the poor, slaves, orphans, widowed and strangers. 'Give justice to the weak and the fatherless; maintain the right of the afflicted and the destitute' (Ps 82:3).

Despite its centrality to holistic development approaches, many evangelicals continue to advocate a separation of human rights as a secular ideal distinct from a biblical approach to social action. In America, conservative Christian politics plays into this separation of human rights as an unintended consequence of free enterprise. In this society a private godliness is promoted which neglects communal responsibility (Townsend 2007). Others in evangelical circles see human rights as liberalism gone global (Hogan 2006).

The ambivalence of evangelical Christian support for human rights is thoroughly examined by Nichols (2009). He argues that in spite of evangelicals' deep historical connection with human rights, there is still little acknowledgement of them both in and outside evangelicalism. Nichols appears ultimately doubtful whether modern evangelical theology is amenable to a robust and deep understanding of and commitment to human rights. A central obstacle to this engagement is the primacy of evangelism as proclamation:

The paradox is that evangelical's missiology - whilst propelling them toward involvement in the human rights movement, particularly in support of religious human rights - is simultaneously a stumbling block in pledging full support for human rights qua human rights. (Nichols 2009:647)

\section{A critique of a Western-style human rights discourse}

Despite its major advances, the HRBA to international development is criticised on several levels. Tomalin (2006), in 'Religion and a rights-based approach to development', observes that there has been an aversion to understanding the ways in which religion and culture shape human rights in different societies. She argues that although religious traditions often act against the pursuit of human rights, there are also overlaps and opportunities for convergence. Her strongest critique is of the universalist, Western-oriented approach, which neglects an indigenous understanding of the mechanisms for pursuing human rights, especially in the global South.

Liberation theologians also identified gaps in the Western language of human rights, which they criticised for its universality as opposed to any partiality towards the poor (Engler 2000). They brought the world's attention back to the millions of 'non-persons' - the poor and marginalised overlooked by proponents of the 1970s and 1980s developmentalism. They insisted that development was a cultural and spiritual challenge as well as a question of transforming socio-economic structures (Cadorette 1996).

Another critique of human rights discourse is its emphasis on individual rights versus collective or people's rights. Hollenbach (1998) argues that contemporary human rights norms originating in the West are in tension with the cultural practices of developing nations. For him, the prevailing economic and political conditions in African countries raise the issue of economic rights, which is different for those in Africa and the West. Human rights takes on a different meaning where extreme want guarantees that African people will not escape oppression, poverty and violence.

These tensions highlight the view that the wholesale adoption of a Western-style human rights is problematic:

Boasting strengths and laden with limitations, the rights-based approach provides a comprehensive tool that will further protect, promote and enhance rights-holders to experience a life of dignity, equality and opportunity, whilst holding dutybearers to account. (Verhaeghe 2009:23)

\section{Holistic development: A Christian HRBA}

Despite the dynamic tensions between 'sacred-secular' approaches to development, the HRBA, with its common ideals of solidarity with the poor, presents an opportunity for engagement between evangelicals and development professionals. This section explores what this would look like in practice for 'evangelical development action'.

From an evangelical perspective, Hiebert \& Hiebert-Crape (1995) define 'development' as:

the movement of people, societies and cultures towards what God intended for them to be as his creation. At the individual level, this includes food, shelter, health, reconciliation with God, freedom from the power of sin, and growth into full humanity, into the image of God. At the social level, it includes justice, equality, genuine community, and harmony with nature. At the cultural level, it includes the knowledge of truth and a meaningful life, experience of joy, and a commitment to righteousness, love, and peace. And at the spiritual level, it involves right relationships with God and one another within the framework of God's Kingdom'. (p. 283) 
The following section explores the multidimensional implications of a holistic approach to Christian development.

\section{Reframing our understanding of poverty}

Poverty is not a simple problem with a simple solution. ChristianAid (2010), an international development agency usefully defines the multidimensional nature of poverty:

Poverty is broad: The concept of poverty is complex and affects many aspects of human lives. Poverty is disempowerment: fundamentally, poverty is a lack of power - power to exercise personal, economic, political or social freedoms. Poverty is political: Poverty is the result not simply of a lack of income or other things in a particular moment of a particular life, but of deeper constraints that are structural in nature. The challenge for ChristianAid is to address these structures, not just to treat the symptoms'. (p. 12)

\section{Understanding the Kingdom of God in the context of poverty}

Both the Old and the New Testament speak of the human condition in a manner connected with salvation of the whole being:

Human rights and welfare, therefore, human liberation, are not situated in the category of 'having,' but primarily within the boundaries that comprise 'being' - including, of course, the implications that flow therefrom for shaping all the situations of human living. (Lehmann 1976)

In this understanding, evangelical concern is directed at both evangelism and social action in an 'integral mission', as described by the Micah Network.

Salvation is not a selfish individualistic act but one that is also about community and cosmos. Stearns (2009) former CEO of World Vision, writing 'The Hole in Our Gospel', laments that 'in our evangelistic efforts to make the good news accessible and simple to understand, we seem to have boiled it down to a kind of "fire insurance" that one can buy.' The truth is that many of the world's poorest people are in fact Christians. Poverty is not only the result of sinfulness and un-Godliness and therefore evangelism cannot be the only medicine.

\section{Adopting and adapting the advocacy and human rights- based approaches (HRBAs)}

Advocacy in solidarity with the poor requires evangelicals to understand poverty not just as a social issue that is helped by humanitarian aid but as a denial of fundamental human rights, which in many countries is at the root cause:

To place advocacy and solidarity at the forefront of mission, however, means that the church will have to challenge the power structure and must question the primacy of economic development over democracy and human rights. This may not be a popular stand within the church as many of its members and, indeed, the church itself may be benefiting from the current power and economic structure. (Wu 1998:218)

The ambiguity of evangelical commitment to human rights (Nichols 2009) also needs urgent examination, especially in the light of the biblical imperatives of human rights as described by Lorenzen (2006). However, it has also been noted that there is a significant gap in the secularist rights language of Western discourse. What does human rights mean for evangelical prophetic witness in the modern world? How do we avoid throwing the baby out with the bath water? How do we recover the same vigour of the slave abolitionists like Wilberforce whilst staying true to our evangelical commitment to bringing the 'good news' into the world?

\section{Taking sides with the poor as partners of change}

The Bible is explicit that God is on the side of the poor and the marginalised:

God's justice does not in the least mean that he is neutral, unconcerned and uninvolved with regard to human misery, distress and suffering or with regard to relationships and structures of injustice, exploitation and oppression. He is the God of justice precisely because he defends and protects those without any rights or those to whom justice is not being done. Taking sides with the poor means that the church might be labelled as radical, as revolutionary, and even as communist. (Wu 1998:219)

Our actions in fighting poverty start in our partnership with the poor and the marginalised. We do this, not as saviours of the poor and oppressed but as brothers and sisters sharing their pain and suffering. We serve them as partners not experts. Partnership with the poor requires that we listen in deep dialogue, which may require us to modify our approaches in serving the poor and oppressed. There are many ways of seeing the poor: as statistics, as objects of charity or as victims of injustice. True humility is seeing the poor as those who represent God. We have an opportunity to know God through the poor and learn from the poor (Chester 2002).

\section{Revisiting the primacy of evangelism}

The evangelism versus social concern approach of churches cannot be relevant in the changing context of the world, where increasingly ministering to the poor and marginalised requires a confrontation of abuses of human rights and human dignity. Understanding missiology from a human rights perspective helps to give some of the context to God's relational working with society at this juncture. Wu (1998) suggests a set of new mission priorities that is responsive and transformative in the context of continuing abuses of human rights.

This requires us to construct paradigms that reflect the complexities of our time and the extensiveness of the missionary task which redefines evangelism as simply proclamation but more holistically as transformational change (Russell 2008). The Rwandan genocide, in which close to a million people were brutally massacred, graphically highlights the complicity of the church through its ambivalence and silence, this in a country where more than $90 \%$ of the population are Christians (Ritner, Roth \& Whitworth 2004). 


\section{The role of the local church}

Christian social action cannot be 'outsourced' to development agencies but needs to be an integral expression of the church's mission into the world. The dual focus of evangelism and social action must be part of the church's understanding and engagement with the world. Verhaeghe (2009) reminds us that despite all of its flaws and its perceived and practised irrelevance, the church is at the same time one of the most resilient as well as one of the most ubiquitous social institutions there is. This is especially so in the African context, where the church is the most universal and the most credible of civil society organisations and an essential institution in the realisation of the Millennium Development Goals.

Evangelical 'sending churches' should be encouraged to explore their role in working with poor communities locally and internationally as partners to the poor. There is also a need to understand the requirement for indigenous churches and Christian leaders who live and work in the communities they serve as opposed to the 'expat Western missionary' approach. Chester (2002), as part of the Micah Declaration, reminds us that the future of integral mission is 'in the planting and enabling of local churches to transform the communities of which they are a part'. This is not a call to re-emphasise the building up of institutional churches based on denominational identity; rather, it is an appeal to re-prioritise communities as the focus of our mission and central to this - our concern for the poor.

\section{Collaborating for the common good}

The notion of common good calls on the Christian community to look beyond individual interests to those of the collective in response to the greatest command of Christ to love our neighbour as ourselves. Jim Wallis (2014), in The (un)common good, reminds us that:

Christianity is not a religion that gives some people a ticket to heaven and makes them judgemental to all others. Rather, it's a call to a relationship that changes all relationships. Jesus told us a new relationship with God also brings us into a new relationship with our neighbour, especially with the most vulnerable of this world, and even with our enemies. But we don't always hear that from the churches. This call to love our neighbour is the foundation for re-establishing and reclaiming the common good, which has fallen into cultural and political - and even religious - neglect. (pp. 3-4)

Our desire for social justice and righteousness will require us to partner with people and organisations of other faiths. In the international development sector, many secular and faith-based organisations work together recognising that the challenge is too big for any one organisation to tackle. Multisectoral and sacred-secular collaboration is required not only at an operational level but also at the level of ideas (Ter Haar 2013). This requires a genuine commitment to understanding the thinking, reasoning and motivation of faith-inspired actors.

The Jubilee 2000 Campaign is a great example of global solidarity and collaboration between evangelicals and other development actors in dealing with a critical human rights issue (Wallis 2005). This grassroots campaign, started in Britain by Christian activists, was quickly supported by Jews, Muslims and secular development NGOs who challenged the International Monetary Fund (IMF) to cancel the debt of the world's poorest nations, mostly in Africa. This was based on the 'Leviticus 25' biblical mandate.

\section{Taking up the South African challenge}

In South Africa, massive poverty remains the biggest challenge in the new democracy. The World Bank (2009) identified South Africa as the eighth most unequal country out of one hundred and forty. Statistics South Africa (2012), using international poverty lines, shows that $10.7 \%$ of the South African population lives below $\$ 1.25$ a day whereas the proportion of those living below $\$ 2.50$ a day estimated at $36.4 \%$. Much of this inequity is the result of the systematic evil of the apartheid regime, supported by a biblical theology of separate development in which the human rights of the majority of South Africans were ignored (Du Toit 2006).

The promise of a democratic South Africa has led to significant changes in the constitutional rights of all South Africans and major economic policy reform that has seen significant development for the country as a whole. However, the problem of the majority of poor people is still with us. What is the role of the evangelical church in the 'new South Africa'? Thesnaar (2008) argues that the Christian church can and must play a central role in implementing in local communities the restorative justice necessary to redress past injustices which perpetuate a divide of offenders and victims or survivors, recognising that restorative justice is essentially a theological issue and not just a political or an economics matter.

Despite these urgent needs, many evangelicals remain resistant to national economic reforms or are oblivious to the tragedy of poverty that still plagues this country, attributing it to corrupt politicians and poor governance only. There is a growing trend towards civic disengagement related to the rights of the poor in the rapidly growing middle class evangelical churches in South African cities - driven by a 'prosperity theology'. In many ways, these churches mimic the National Development Agenda, promoting job advancement, wealth creation, praying for national prosperity and social giving in the name of faith in favour of the middle class. In these mega-churches, the care for the poor is delivered through denominational social foundations and branded as part of the churches' ministry. In a case study of 'His People' church, Czeglédy (2008) illustrates some of these tensions evident in charismatic Christianity's adapting to a post-apartheid South Africa.

It is clear that evangelicals across the spectrum have played a significant role in South Africa's democratisation. The advent of the new dispensation in 1994 was accompanied by 
an increase in the participation of previous liberation fighters into active politics. Sadly, the new era:

has demonstrated how quickly the past-with its tortured theological and ideological justifications and awkward silencescan be forgotten and the new can be embraced with enthusiasm and the possibility of fresh opportunities. (Balcomb 2004:34)

These 'fresh opportunities' also come with their attendant consequences of corruption, poor governance and personal enrichment at an individual leadership level. Balcomb (2004) argues that these challenges cannot be addressed only by legal instruments but come from changed habits and dispositions. Religion is central to changing values and beliefs. The church must take an active advocacy role, collaborating with civil society actors in dealing with current social challenges and especially the injustice of poverty.

There is an urgent need for South African leaders, in all sectors of society and especially in government, to act with moral courage and conviction. Kretszchmar (2007) argues that the formation of the moral character of leaders, though complex, is preferable to surrendering to the abuse of power, despair, inertia or cynicism. Changed hearts and minds will not come through legislative reform alone. Evangelicals can play a constructive role in building up leaders whilst at the same time challenging social immorality, especially as it has an effect on justice towards the poor.

South African evangelicals have enthusiastically embraced the new Constitution for its right to religious freedom. Middle class evangelicals have consistently claimed to be the moral voice on issues such as abortion, homosexuality, crime, corruption and equal opportunity whilst paying little attention to the plight of the poor, which is the biggest social scourge in this country.

Evangelicals are called to be 'light and salt' in a country in which the majority claims to be Christian; where religious pluralism is valued and the constitutional rights of all its citizens are guaranteed. There is a great opportunity for evangelicals to take the lead in partnering with government, civil society, international and national NGOs in bringing about a change in the lives of the poor, based on the biblical call for justice and righteousness.

\section{Conclusion}

It is time for evangelicals to reclaim their heritage of commitment to local and international development equally valuing both evangelism and social action as integral to Christian mission. There is also an urgent need to re-engage with human rights as a viable instrument of advocacy on behalf of the poor and not just limit action to mercy ministries addressing symptoms but to also deal with issues of social justice - getting to the root causes of global poverty. Given the disenchantment with secularism as the driving model of international development, there is a pressing need for evangelicals to collaborate with INGOs, NGOs and other faith-based organisations in their common commitment towards the poor, recognising the centrality of religion to development. Evangelicals in South Africa have a critical prophetic role to play in addressing the injustice of poverty in South Africa, by adopting a human rights approach. In addition to continued commitment to ministries of compassion, there is also a need to challenge the structures of power and authority that perpetuate poverty whilst calling on all South Africans to strive towards building a society inspired by the biblical values of justice and righteousness.

\section{Acknowledgements Competing interests}

The author declares that he has no financial or personal relationship(s) that may have inappropriately influenced him in writing this article.

\section{References}

ActionAid, 2012, 'People's action in practice, ActionAid's Human Rights Based Approach 2.0', viewed n.d., from http://www.people-action.org

Balcomb, A., 2004, 'From apartheid to the new dispensation: Evangelicals and the democratization of South Africa', Journal of Religion in Africa 34(1/2), 1-35.

Bragg, 1989, 'Theological reflections on assisting the vulnerable', in E.J. Elliston (ed.), Christian relief and development: Developing workers for effective ministry, Word Publishing, Dallas.

Cadorette, C., 1996, 'Liberating mission: A Latin American perspective', in W. Saayman \& K. Kritzinger (eds.), Mission in bold humility: David Bosch's work considered, Orbis, New York.

Chester, T., 2002, Justice, mercy and humility. Integral mission and the poor, Paternoster Press, Milton Keynes.

ChristianAid, 2010, 'Doing justice to poverty: ChristianAid's understanding of poverty and its implications', ChristianAid position paper, viewed n.d., from http://www. ChristianAid.org

Czeglédy, A.P., 2008, 'A new Christianity for a new South Africa: Charismatic Christians and the post-apartheid', Journal of Religion in Africa 38(3), 284-311. http:// dx.doi.org/10.1163/157006608X323504

Du Toit, C.W., 2006, 'Religious freedom and human rights in South Africa after 1996 Responses and challenges', Brigham Young University Law Review 3, 677-698.

Engler, M., 2000, 'Toward the "Rights of the Poor": Human Rights in Liberation Theology', The Journal of Religious Ethics 28(1), 339-365. http://dx.doi. org/10.1111/0384-9694.00053

Ferris, E., 2005, 'Faith based and secular humanitarian organisations', International Review of the Red Cross 87(858), 311-325. http://dx.doi.org/10.1017/ S1816383100181366

Gelot, L., 2012, 'Secularisation as an international crisis in legitimacy', Politics and Religion 6(1), 61-86.

Green, S.W., 2011, 'Report on Lausanne Cape Town 2010', International Bulletin of Missionary Research 35(1).

Hearn, J., 2002, 'The "invisible" NGO: US evangelical missions in Kenya', Journal of Religion in Africa 32(1), 32-60. http://dx.doi.org/10.1163/15700660260048465

Hiebert, P.G., 2009, The Gospel in human contexts: Anthropological explorations for contemporary missions, Baker Academic, Ada.

Hiebert, P.G. \& Hiebert-Crape, B., 1995, 'The role of religion in international development', Conrad Grebel Review 13, 281-298.

Hofer, K., 2003, 'The role of evangelical NGOs in international development: A comparative case study of Kenya and Uganda', Spectrum 38(3), 375-398.

Hogan, L., 2006, 'A different mode of encounter', Political Theology 7(1), 59-73. http://dx.doi.org/10.1558/poth.2006.7.1.59

Hollenbach, D., 1998, 'Solidarity, development, and human rights: The African Challenge', The Journal of Religious Ethics 26(2), 305-317.

Jones, B. \& Petersen, M.J., 2011, 'Instrumental, narrow, normative? Reviewing recent work on religion and development', Third World Quarterly 32(7), 1291-1306. http://dx.doi.org/10.1080/01436597.2011.596747

Kretszchmar, L., 2007, 'The formation of moral leaders in South Africa: A Christianethical analysis of some of the essential elements', Journal of Theology for Southern Africa 128, 18-36.

Lehmann, K., 1976, 'Human development and Christian salvation', International Theological Commission, 117-128.

Ljungman, C.M., 2004, 'Applying a rightsbased approach to development: Concepts and principles', Conference paper: The winners and losers from rightsbased approaches to development, viewed n.d., from http://www.sed. manchester.ac.uk/ 
Lorenzen, T., 2006, 'Freedom from fear: Christian faith and human rights today', Pacifica, 19, 193-212.

Mayotte, J.A., 1998, 'Religion and global affairs: The role of religion in development', SAIS Review 18(2), 65-69. http://dx.doi.org/10.1353/sais.1998.0038

Moksnes, H. \& Melin, M. (eds.), 2013, Faith in civil society: Religious actors as driver of change, Uppsala Centre for Sustainable Development, viewed n.d., from http:// www.csduppsala.uu.se

Nichols, J.A., 2009, 'Evangelicals and human rights: The continuing ambivalence of evangelical Christians' support for human rights', Journal of Law and Religion XXIV 629-662.

Pierson, P.E., 1989, 'Missions and community development: A historical perspective', Christian Relief and Development, Word, Dallas.

Ritner, C., Roth, J.K. \& Whitworth, W., 2004, Genocide in Rwanda: Complicity of the churches?, Paragon House, Saint Paul.

Russell, M., 2008, 'Christian mission is holistic', International Journal of Frontier Missiology 25(2).

Shortt, R., 2012, Christianophobia. A faith under attack, Random House, London.

Shik, O.H.J., 1983, Mission and development in mission in the context of endemic poverty, Christian Conference of Asia, Singapore, pp. 166-172.

Statistics South Africa, 2012, Living conditions survey, viewed n.d., from http://www. statssa.gov.za

Stearns, R., 2009, The hole in our Gospel, Thomas Nelson, Nashville.

Stott, J. 2006. Issues facing Christians today, Zondervan, Grand Rapids.
Ter Haar, G., 2013, 'Mixed blessings: Religion in contemporary politics', in H. Moksnes \& M. Melin (eds.) Faith in civil society: Religious actors as drivers of change, Uppsala Centre for Sustainable Development, Uppsala.

TerHaar, G. \& Ellis, S., 2006, 'The role of religion in development:towardsanew relationship between the European Union and Africa', The European Journal of Development Research 18(3), 351-367. http://dx.doi.org/10.1080/09578810600893403

Thesnaar, C., 2008, 'Restorative justice as a key for healing communities', Religion \& Theology 15, 53-73. http://dx.doi.org/10.1163/157430108X308154

Tomalin, E., 2006, 'Religion and a rights-based approach to development' Progress in Development Studies 6(2), 93-108. http://dx.doi. org/10.1191/1464993406ps130oa

Townsend, K.K., 2007, Failing America's faithful. How today's churches are mixing god with politics and losing their way, Warner, New York.

UNHCR, 2006, 'Frequently asked questions on a human rights-based approach to development cooperation: UNHCR HR/PUB/06/8', United Nations, New York/ Geneva.

Verhaeghe, I., 2009, 'The role of the church in promoting rights-based approaches to disaster management', MA Centre for Development \& Emergency Practice (CENDEP), Oxford Brookes University, Oxford.

Wallis, J., 2005, God's politics, Lion Hudson, Oxford.

Wallis, J., 2014, The (un)common good: How the gospel brings hope to a world divided, Brazos Press, Michigan.

World Bank, 2009, World development indicators, viewed n.d., from http://www.data. worldbank.org

Wu, R., 1998, 'Standing with the poor or powerful?', International Review of Mission 87, 345. http://dx.doi.org/10.1111/j.1758-6631.1998.tb00080.x 